\title{
Ecological roles and threats to aquatic refugia in arid landscapes: dryland river waterholes
}

5 Fran Sheldon $^{\mathrm{A}, \mathrm{B}}$, Stuart E. Bunn ${ }^{\mathrm{A}}$, Jane M. Hughes ${ }^{\mathrm{A}}$, Angela H. Arthington ${ }^{\mathrm{A}}$, Stephen

R. Balcombe ${ }^{\mathrm{A}}$ and Christine S. Fellows ${ }^{\mathrm{A}}$

A Australian Rivers Institute, Griffith University Nathan, Queensland 4111, Australia

${ }^{B}$ Corresponding author. Email: f.sheldon@griffith.edu.au

\begin{abstract}
Dryland rivers are renowned for their periods of 'boom' related to the episodic floods that extend over vast floodplains and fuel incredible production, and periods of 'bust' where the extensive channel network is restricted to the permanent refugial waterholes. Many of these river systems are unregulated by dams but are under increasing pressure, especially from water abstraction and overland flow interception for agriculture and mining. Although some aquatic organisms with desiccation-resistant life stages can utilize ephemeral floodplain habitats, the larger river waterholes represent the only permanent aquatic habitat during extended periods of low or no flow. These waterholes act as aquatic refugia in an otherwise terrestrial landscape. Variable patterns of connection and disconnection in space and time are a fundamental driver of diversity and function in these dryland river systems, and are vital for dispersal and the maintenance of diverse populations, generate the spatial and temporal variability in assemblage structure for a range of different organisms and fuel the productivity that sustains higher trophic levels. Changes to natural patterns of connection and disconnection of refugial waterholes, owing to water resource development or climate change, will threaten their persistence and diminish their functional capacity to act as aquatic refugia.
\end{abstract}


Over 50\% of the world's land area could be termed “drylands” (Tooth 2000), encompassing hyper-arid, arid, semi-arid and dry-subhumid climatic regions. Although relatively poorly studied, the 'dryland rivers' that flow through these regions are common features (Walker et al. 1995; Kingsford and Thompson 2006). In dryland regions, evaporation often exceeds rainfall and many rivers cease to flow for extended periods of time, fragmenting into disconnected waterholes and wetlands. For example, in South Africa, where $60 \%$ of the land area is classed as arid to semi-arid, $40 \%$ of the $65,000 \mathrm{~km}$ of river channels are subject to interruptions of flow (Davies et al. 1994). Most of the western flowing rivers of Namibia are ephemeral for much of their length and, for most of the year, the channels contain significant wetlands and waterholes (Breen 1991; Loutit 1991). Dryland rivers, however, are just one sub-group of the broader group of temporary or ephemeral rivers, which are considered to be the most common and hydrologically dynamic of all freshwater ecosystems, occurring across most of the planet, and including rivers in alpine areas as well as temperate zones (Stanley et al. 1997; Larned et al. 2010).

45 In Australia, 92\% of the 3.5 million km of river channels measured at the 1:250,000 scale are lowland rivers (Thoms and Sheldon 2000a), and with 75\% of the land area classed as arid to semi-arid, most of these lowland rivers can be characterized as dryland rivers whose hydrographs demonstrate periods of no flow, and are therefore ephemeral rivers. Australian dryland rivers have distinctive ecologies, intimately linked to their highly variable flow regimes (Walker et al. 1995; Sheldon and Puckridge 1998; Bunn and Davies 1999; Puckridge et al. 2000). Their unique combination of flow variability and geomorphic complexity creates a distinctive boom and bust ecology (Walker et al. 1995; Kingsford et al. 1999; Kingsford 2000a; Bunn et al. 2006a), characterized by episodes of intense reproduction and high productivity by opportunistic plants and animals (Puckridge et al. 2000; Bunn et al. 2006b). Jim Puckridge was one of the first to document this in his studies of fish communities in the Coongie Lakes region of the Cooper Creek, Lake Eyre Basin, Australia, describing the exponential increase in diversity, and explosion of abundance and biomass, associated with sequential flooding through this usually dry system (Puckridge 1999).

60 The Lake Eyre Basin (LEB) rivers, along with other dryland rivers, are renowned for their incredible productivity during periods of flooding - the "boom” (Puckridge 1999; Bunn et al. 
2006b, Balcombe et al. 2007; Kingsford, this issue), but fundamental to this ability to respond to flooding is the maintenance of viable habitats during the extended dry periods, the “bust”. For much of the time, Australia's dryland rivers exist as a network of ephemeral channels and turbid waterholes. The contrasting states of flood and drought mean that dryland rivers fluctuate between being highly 'fragmented' systems where aquatic habitats (pools or waterholes (cf. Knighton and Nanson1994)) exist as disconnected aquatic 'islands' in an otherwise terrestrial landscape, and highly connected, as during floods, when all aquatic habitats are connected via inundation. Fragmentation is a natural feature of rivers and at small spatial scales has been shown to contribute to a high degree of habitat heterogeneity (Cooper et al. 1997). The demonstrated high flow variability of Australian dryland rivers in both space and time (Walker et al. 1995; Puckridge et al. 1998; Thoms and Sheldon 2000b) suggests habitat fragmentation, particularly at the reach scale, is likely to be extreme in these systems. During dry periods, the larger waterbodies, or 'waterholes', represent the only aquatic habitat for biota requiring permanent water to survive (Arthington et al. 2005; Bunn et al. 2006a). Although some aquatic organisms with desiccation-resistant life stages may be able to utilize ephemeral aquatic habitats on the floodplain (Boulton and Lloyd 1992; Jenkins and Boulton 2003), permanent and semi-permanent river waterholes are likely to function as refugia for a wide variety of aquatic organisms (Morton et al. 1995).

Rivers in the LEB and northern regions of the Murray-Darling Basin (MDB) of Australia (Figure 1) are typical of dryland rivers. Many are essentially unregulated but are becoming the focus of major developments that have a high water demand (e.g. intensive irrigated agriculture Kingsford et al. 1998; Lemly et al. 2000; Kingsford 2000a; Kingsford 2006). Both water abstraction and interception of overland flows on floodplains are increasing across the region, as are the number and size of on-farm storages (Lutton et al. 2010). For example, from 1993/94 to 1997/98, the number of on-farm water storages in the CondamineBalonne and Border Rivers basins, northern MDB (Figure 1) increased by 90\%, representing an increase of over $50 \%$ in diversions of overland flows and water privately diverted from rivers.

90 The Murray-Darling and Lake Eyre basins have several river and wetland habitats that are recognized as being significant for the maintenance of biodiversity, including the Narran Lakes, Bulloo Overflow, Paroo Wetlands and all of the permanent wetland complexes and waterholes within the LEB (Morton et al. 1995) (Fig. 1). Key threats to the maintenance of 
diversity and ecological processes within these habitats, include land degradation through over-grazing and cropping, alterations to the hydrological regime through water resource development and invasions by exotic plant and animal weeds (Morton et al. 1995). In this paper, we demonstrate the importance of waterholes as refugia in dryland river catchments, both for maintaining aquatic biodiversity and biophysical processes during extended dry periods. Given this, we test the hypothesis that aquatic biodiversity in dryland rivers reflects spatial and temporal patterns of connectivity in the landscape.

Figure 1 here

\section{The Concept of Refugia}

105 In the general ecological literature, definitions of refugia follow two broad themes. The first defines a 'refuge' as a habitat that supports populations not able to live elsewhere in a landscape (Nekola 1999). The second includes the role of adversity, where refugia are defined as places (or times) where the negative effects of disturbance are lower than in the surrounding area (or time) (e.g. Lancaster and Belyea 1997). During adverse conditions, organisms in refugia have a high probability of survival and these organisms are subsequently available to recruit or recolonise more severely affected areas of the landscape (Lancaster and Belyea 1997).

The terms 'refugium' or 'refuge' have been used widely in the aquatic literature, in relation to drought conditions (Wood and Petts 1999), floods and high flows (Winterbottom et al. 1997; Rempel et al. 1999), thermal stress (Johnson et al. 1998; Torgersen et al. 1999) and predation (Dudgeon 1996). Sedell et al. (1990) define riverine refugia to include localized microhabitats and/or zones within the channel, unique reaches, riparian vegetation, floodplains and groundwater. Riverine refugia are seen to exist as gradients or continua in both space and time.

120 In ephemeral rivers, including dryland rivers, aquatic habitat expands and contracts dramatically over both large and small spatial scales under natural flow regimes (Stanley et al. 1997). It is clear that any definition of 'refugia' is essentially taxon-specific and episodic 
floods may be favourable (boom times) for some species but represent adverse times to be endured and survived by others before returning to favoured dry periods (see Puckridge 1999; Jenkins and Boulton 2003). Mechanisms of refugium use are diverse and depend on the spatial and temporal attributes of the physical environment and the requirements of the organism (Lancaster and Belyea 1997). In dryland rivers, for example, refugia for aquatic plants may include 'safe sites' for seed storage, germination, establishment and plant reproduction (Capon 2003). For fish and many fully aquatic invertebrates, however, the only refugia during dry periods are likely to be permanent river waterholes (Arthington et al. 2005; Marshall et al. 2006).

Given the varying refugial requirements of different biota in dryland river systems, we suggest that no single type of waterhole would provide adequate conditions for all aquatic biota. Rather, a spatial and temporal mosaic of refugia providing a range of conditions would more adequately allow different sub-sets of the regional biota to survive dry periods (Bunn et al. 2006a). It may not be possible to identify just a few refugia within this mosaic. Whether a particular waterhole constitutes a refugium for any one taxon may vary temporally, as the advent of floods can cause changes in their biophysical attributes. For example, a physically ideal refugium with adequate water quality for many fish species might become intermittently hostile if flooding brings in a few large piscivorous fish, which colonize and persist into the drying phase (Kennard 1995). Temporal variation in waterhole conditions might be necessary for maintenance of diverse assemblages, by providing ideal conditions for a variety of taxa from plants to invertebrates and fish. 


\section{Dryland River Waterholes as Aquatic Refugia}

\section{Permanent hydrological features}

To serve as refugia for aquatic organisms, waterholes in dryland river networks must be hydrologically permanent or semi-permanent features in the landscape. As a fluvial feature, waterholes are physically diverse (Knighton and Nanson 1994), covering a broad range of shapes and sizes (Davis et al. 2002). However, in general, most waterholes in the dryland rivers of the LEB and MDB, Australia, are longer than they are wide and $<2-3 \mathrm{~m}$ deep (Davis et al. 2002). Despite occurring in a region where annual evapotranspiration typically exceeds $2 \mathrm{~m}$, some waterholes persist for several years in the absence of surface flow or local rainfall (Bunn et al. 2006a). Of the 170 named waterholes in the channel country of Cooper Creek, 80 have been estimated to persist for one year without flow or rainfall and only 5 have been estimated to persist beyond two years (Bunn et al. 2006b). The degree to which shallow groundwater contributions influence waterhole permanence is likely to vary across different river catchments, however, for the waterholes in the channel country of Cooper Creek, LEB, groundwater inputs were found to be minimal or non-existent (Hamilton et al. 2005). This highlights the importance of in-channel flows for maintaining water levels between large flow events in these typically isolated refugia.

\section{Dispersal between waterholes}

Under low flow or 'disconnected' conditions, dryland river waterholes exist as aquatic islands, or patches, in a terrestrial landscape. In terrestrial systems, increasing habitat fragmentation usually includes a reduction in habitat fragment size, increasing isolation between habitat fragments and loss of habitat (Andren 1996; Gustafsson and Gardner 1996). While waterbirds are known to perceive dryland river environments on large regional scales, and move freely between aquatic "patches” (waterholes) over large distances (Roshier et al. 2008; Kingsford this issue), organisms that perceive the landscape at fine scales are restricted to local habitat patches and are highly influenced by connection between these patches. Therefore, the long-term persistence and stability of populations within fragmented landscapes, such as dryland rivers, will depend on their rates of dispersal and recolonisation among waterholes (Gustafsson and Gardner 1996). 
Analysis of the patterns and levels of genetic differentiation among populations of aquatic organisms has been used to infer the mechanisms and extent of dispersal among them (Hughes et al. 1995). This approach assumes that if dispersal between patches is high, and thus gene flow is high, little genetic differentiation among populations is expected; however, if dispersal is restricted, genetic differentiation among populations will occur due to natural selection and/or random genetic drift (Slatkin 1985). Analysis of the genetic diversity between populations can, therefore, be used to infer the extent and potential mechanisms of dispersal (e.g. Sweeney et al. 1986; Waples 1987; Jackson and Resh 1992). For many aquatic taxa, waterholes during low flow are similar to oceanic islands; they have "hard edges" or low "permeability" (Holmquist 1998). There is likely little to no movement between the waterholes by truly aquatic taxa during these periods, but perhaps higher movement of semi-aquatic taxa such as insects and waterbirds. However, at intermediate and high flow levels there may be strong connections between waterhole "patches", allowing major movements and dispersal by truly aquatic organisms.

Data collected from waterholes in the LEB suggest that although dryland rivers appear to be highly fragmented in space and time, this fragmentation may not be evident in the genetic diversity of their inhabitants (Table 1). While many aquatic taxa may not be able to disperse freely between isolated waterholes when flow ceases or is low, for most taxa waterholes will become connected through in-channel flows within their life cycles and real fragmentation is therefore limited. The biota of Australian dryland rivers reflect three hypothetical dispersal 'modes'. For those organisms that are not truly aquatic, connection between waterholes, even under drought conditions, may be high through the riparian network (Lynch et al. 2002). These organisms include many of the aquatic insects with terrestrial adults, such as the Hemiptera and Coleoptera; they are the ‘movers' or ‘mobile-link' organisms (sensu Lundberg and Moberg 2003) (Fig. 2). Although the population genetics of highly mobile insects ('mobile links') such as Hemiptera or Coleoptera are yet to be explored in dryland river waterholes, their abundance in both ephemeral and permanent habitats (Sheldon et al. 2002; Marshall et al. 2006) suggests they move freely throughout the channel network even during periods of low flow.

Another large group of organisms, the 'networker' organisms, may be restricted to refugial waterholes when flows are low, but can rapidly disperse between waterholes in the channel network when waterholes are connected (Fig. 2). In Australian dryland rivers, this 
'networker' group includes many of the fish and crustaceans (Table 1). Common population traits of these organisms are low levels of genetic diversity within catchments but high levels between catchments, suggesting free dispersal between refugia during periods of connectivity (Table 1). Within this group, however, there is evidence of variation in the ability to disperse throughout the network during connection. For example, the small glassfish Ambassis spp. displays evidence of within-catchment population structure, based on genetic diversity, suggesting some dispersal but perhaps not over large distances (Huey et al. in review). In comparison, many of the larger fish displayed very little within-catchment population structure, based on genetic diversity, suggesting extensive dispersal throughout the stream network (Huey et al. 2006; Hughes and Hillyer 2006) (Table 1).

A third group, the 'permanent refugials' are entirely restricted to refugial waterholes, showing very limited dispersal even under flow conditions (Fig. 2). Of the taxa reviewed, only some of the molluscs show dispersal patterns that can be described as 'permanent refugial'; both the viviparous gastropod Notopala sublineata and the freshwater mussel Velesunio spp. showed high levels of within-catchment population structure, based on genetic diversity, suggesting limited dispersal throughout the channel network (Carini et al. 2006; Hughes et al. 2004; Table 1). The dispersal patterns of the freshwater mussel Velesunio spp. are particularly interesting given that its larvae are parasitic on fish hosts. Gene flow analysis suggests the fish hosts disperse readily during waterhole connection while, in contrast, the mussels rarely disperse, with high between-waterhole differences in genetic diversity. We conclude, therefore, that these mussels spawn only during low or no flow when dispersal between waterholes by fish is limited or impossible.

Table 1 here

Figure 2 here

In large rivers, the flood pulse is a mediator of disturbance influencing both diversity and processes by connecting the river with its floodplain (Junk et al. 1989, Walker et al. 1995), and likewise, the periods between floods (periods of low or no flow) can be just as important drivers of riverine function. In dryland rivers, the variability in the magnitude, duration and 
240 frequency of flooding over long time scales (20+ years) (cf. Puckridge et al. 2000) drives high spatial variability in the connection frequency of different parts of the river network. Ward et al. (1999) found $\alpha$-diversity (local or site scale diversity; within-community diversity) of fish assemblages to decrease with increasing disconnection of waterbodies whereas $\beta$-diversity (between site diversity; between-community diversity) increased. Evidence from Australian dryland rivers also suggests that the greatest degree of biotic variance lies at the waterbody scale. In the Goyders Lagoon wetland complex on the Diamantina River, LEB, variation in fish assemblage composition was higher at the waterbody scale than between sites within waterbodies (Puckridge et al. 1999), while macroinvertebrate assemblages of the same sites also varied more strongly between waterbodies than between microhabitats within waterbodies (Sheldon and Puckridge 1998). A similar pattern was found for fish in waterbodies of Coongie Lakes (Puckridge 1999) and Cooper Creek (Arthington et al. 2005) and for Coongie Lakes invertebrates (Sheldon et al. 2002). Looking at wetlands associated with dryland rivers, across a broad range of inundation frequencies, Jenkins and Boulton (2003) found the diversity of microinvertebrates hatching from inundated sediment reflected time since last inundation, with similar patterns found for floodplain plants (Capon 2003)

Site-specific community composition, and hence biodiversity, is the result of an interplay between both local and regional biotic and abiotic factors which act as "filters" (Poff 1997). Dryland rivers can be abiotically very harsh environments with extremes in the range of hydrological and physico-chemical variables (e.g. oxygen, conductivity, $\mathrm{pH}$, temperature), particularly during periods of low or zero flow (Magalhaes et al. 2002; McMahon and Finlayson 2003; Sheldon and Fellows this issue). In the channel country of Cooper Creek, the variability in macroinvertebrate composition at one site through hydrological cycles of flooding and drying was far greater than large-scale spatial variability at any one point in time (Marshall et al. 2006). A similar pattern was apparent for fish assemblages, with increasing changes in fish assemblage structure with increasing time since the last flood (Arthington et al. 2005; Balcombe and Arthington 2009) and for algal assemblages, with high levels of spatial and temporal variability (McGregor et al. 2006). This suggests that biodiversity does vary both spatially and temporally, reflecting the heterogeneity of connection in large floodplain rivers (Bornette et al. 1998; Tockner et al. 1999; Amoros and Bornette 2002). 
We suggest that a natural level of connectivity between waterholes is integral in the maintenance of their ecological function. Assemblage dynamics within refugia are likely to change with increasing time since last connection, and biodiversity may be highest in refugia subject to some form of 'intermediate' level of connectivity (Marshall et al. 2006). Comparative data from four Australian dryland rivers suggested that during periods of prolonged connection, both environmental and hydrological 'filters' will be homogeneous across a broad range of habitats, and assemblages may show very little dissimilarity (Sheldon and Thoms 2006) (Figure 3). As flood levels recede and connection between waterholes is lost, assemblages in discrete waterholes will diverge in response to a broad range of localised conditions including water quality (Sheldon and Fellows this issue), local waterhole complexity (Arthington et al. 2005; Davis et al. 2002), waterhole permanence (Hamilton et al. 2005), productivity (Burford et al. 2008; Fellows et al. 2009) and perhaps the presence or absence of predators. If disconnection is maintained, the environment within the waterhole will become increasingly harsh with only tolerant generalists able to survive (Fig. 3).

Figure 3 here 
There is increasing interest in the relationship between biodiversity and ecosystem function for many different ecosystems (see Loreau 2000). To sustain biotic assemblages, refugia must provide adequate and diverse food resources; a low diversity of food resources may lead to low trophic diversity in consumers and consequently reduced species richness. To function as refuges in the long-term, waterholes also need to be sites where organisms can maintain viable populations while the rest of their habitat is fragmented or dehydrated, suggesting they have to meet the productivity requirements that sustain higher trophic levels.

Existing ecosystem models of large rivers have emphasized the importance of lateral (Junk et al. 1989) or longitudinal (Vannote et al. 1980) inputs of terrestrial organic matter as a source of organic carbon for aquatic consumers. In unimpacted large rivers, the main channel habitats have varying degrees of dependence on their associated floodplain for energy, and vice versa (Tockner and Stanford 2002). Junk et al. (1989) demonstrated the strong dependence of the Amazon main channel on its floodplain habitats, driven by the very predictable seasonal flood pulse. At the other end of the hydrological continuum, however, Walker et al. (1995) suggested that the main channels of dryland rivers would not have the same floodplain dependence given their high variability and the unpredictability of floodplain inundation.

Despite this, the extensive floodplains and network of anatomising channels and distributaries in many dryland rivers provide a far greater terrestrial-water interface than would occur with a single large channel river (Walker et al. 1995; Bunn et al. 2006a). Many Australian dryland rivers are often highly turbid and may remain so, even during the long no-flow periods (Sheldon and Fellows this issue). Given their extensive terrestrial-aquatic interface, high turbidity and low light penetration, we predict that populations of aquatic consumers would depend on fluxes of energy and nutrients derived from extensive floodplain exchange during floods (cf. FPC: Junk et al. 1989), even infrequent and unpredictable floods, and by continual input from fringing vegetation persisting along the vast network of channels during dry periods (Bunn et al. 2003). We also predict that aquatic plant production should be limited by low light penetration in the turbid water and thus make a minor contribution to energy flow through the aquatic food web; however, this is not the case (Bunn and Davies 1999; Bunn et al. 2003). Despite their high natural turbidity, the permanent river waterholes 
of LEB rivers support a highly productive band of filamentous algae restricted to the shallow littoral margins. Stable isotope analysis has revealed that this "bathtub ring" of algae is the major source of energy driving the aquatic food web of Cooper Creek waterholes, supporting large populations of snails, crustaceans and fish (Bunn et al. 2003). Periodic phytoplankton blooms and zooplankton may also be important components of the food web under specific flow conditions (see Balcombe et al. 2005; Medeiros and Arthington 2008).

Given the degree of dependence on littoral primary production and the narrow photic zone (typically $<30 \mathrm{~cm}$ ), channel morphology clearly plays a major factor in overall productivity at the waterhole scale. We predict that waterholes with shallow sloping banks and bars will be more productive than those with more vertical banks and a restricted photic zone. For example, two waterholes may have similar overall dimensions in terms of length and width, but one with three times the area of shallow habitat is likely to have approximately three times the production (Fellows et al. 2009). Across Australia's dryland rivers, there is a great diversity of waterholes, and while predominantly those occurring within the lowland river networks tend to be turbid with low levels of light penetration, there are some, particularly those in the middle and upper reaches of the rivers, and those associated with the vast riverine wetlands (see Leigh et al. this issue), where the water is clearer, light penetration is greater and the waterholes can be dominated by macrophytes. The dominance of algal carbon over allochthonous sources, in these waterholes is as yet unexplored. However, given its importance in the highly turbid waterholes, we may expect a similar outcome.

For dryland rivers, waterholes identified as refugia are physically stable over long periods (Knighton and Nanson 1994). The degree of hydrological permanence of these waterholes during dry periods reflects a balance between high rates of evaporation, water use by riparian trees and intermittent surface flows; there is very little evidence of shallow groundwater inputs (Hamilton et al. 2005). Variability in hydrological connection combined with high levels of turbidity likely drive variability in ecosystem function among waterholes (Fig. 4) (Fellows et al. 2009). Flooding is a distinct phase of the hydrological cycle and although the timing, magnitude and duration of flooding in these dryland rivers is highly variable (Puckridge et al. 1998), it always results in the inundation of vast areas of floodplain and incredible productivity (Puckridge et al. 2000; Bunn et al. 2006b; Balcombe et al. 2007). 
We suggest that processes occurring within waterholes between large flood events are also important and reflect different hydrological conditions (Fig. 4). In-channel flows, or flow pulses can occur before or after a large flood or occur independently in association with localised rainfall (Bunn et al. 2006a). These flows are important for maintaining connection and therefore dispersal between waterholes but do not allow the establishment of either benthic algal communities, as the inundation period is too brief, or substantial pelagic production due to high river flows. Thus during in-channel flow pulses, production in these waterholes is low (Fellows et al. 2009) and may not be sufficient to support higher trophic levels (Balcombe et al. 2005; Balcombe et al. 2007). Once flow ceases, there is a rapid decline in water depth within a waterhole until the height of the outflow sill is reached. During this initial phase of flood recession, there is very little littoral primary production algal spores in previously dry sediments may become active but not reach high production levels during the short window of inundation. Once a stable sill height is reached, water depth declines primarily as a function of evaporation (Hamilton et al. 2005). During this increasingly stable period, there are typically high levels of production associated with a well-established benthic algal community (Fellows et al. 2009). This highly productive "bath-tub" ring appears to be able to track the water levels slowly declining through evaporation, fuelling both invertebrate and fish production within isolated waterholes (Bunn et al. 2003; Burford et al. 2008).

\section{Conclusions and impacts of water resource development on refugia}

In this paper, we have suggested that hydrological variability, through variability in waterhole connectivity, is a vital driver of biodiversity and ecosystem function in dryland river waterholes. Patterns of connectivity between waterholes in the channel network influence the dispersal of plants and animals and mediate population structure, and connectivity patterns between waterholes in both space and time drive patterns in assemblage structure. Different phases of the hydrograph, from connected to disconnected, influence in-channel processes and maintain the productivity of refugia, even during extended periods of no flow or groundwater input. This dominant role of connection and disconnection in driving patterns of biodiversity and biophysical processes in Australian dryland rivers concurs with the general concepts of temporary river ecology outlined by Larned et al. (2010), where hydrological connectivity controls meta-community and meta-ecosystem dynamics (Concept 1), aquatic- 
terrestrial habitat mosaics influence biodiversity (Concept 2) and flow pulses trigger biophysical processes (Concept 3). These observations are not new, as similar influences of connection - disconnection, or expansion- contraction, on both biodiversity and biophysical processes were outlined for desert streams by Stanley et al. in (1997). However, their general nature, across a broad suite of ephemeral rivers, highlights the importance of not only the flood phase of the hydrological cycle, of which there has been much published (Junk et al. 1989; Heiler et al. 1995; Tockner et al. 2000), but also on the low, or no, flow phase, when there is maximum contraction in ephemeral streams. Most importantly, however, it highlights the ecological significance of the pattern of hydrological connection disconnection (expansion and contraction) that the alternate states of flooding and drying provide.

Throughout the Australian arid region, the position of many homesteads and settlements on the banks of large permanent waterholes is testimony to their relative longevity. However, this physical and hydrological permanence in an arid landscape makes the waterholes targets for land and water resource development (Kingsford 2000a, 2000b). Water resource development can alter the natural dynamics of connectivity in river systems and could fundamentally impact the refugial role of dryland river waterholes (Kingsford 2000a; Thoms and Sheldon 2000b). Globally, the ecological consequences of fragmentation of permanent river channels by dams or barriers are significant (Ward and Stanford 1995; Dynesius and Nilsson 1994; Bunn and Arthington 2002). Construction of dams or weirs on the river network causes upstream impoundment and the maintenance of high water levels along much of the channel network, thus constant connection between waterholes and a loss of "refugia function”.

Modelling the impact of water resource development on the hydrology of rivers in Australia's wet-dry tropics, Leigh and Sheldon (2008) suggested that those rivers with a 'dryland' flow signal (high levels of flow variability) were likely to suffer increasing regularity with a reduced frequency of both low flows and high flows under water resource development, namely flow abstraction. This reflects the situation in many regulated rivers in the northern Murray-Darling Basin, Australia, which are either highly regulated and no longer experience periods of 'low-flow', and therefore waterhole disconnection, or are subject to extreme levels of water abstraction for irrigated agriculture and therefore greatly reduced connection both spatially and temporally (Kingsford 2000a; Thoms and Sheldon 2000b). Given the extreme 
hydrological variability in dryland rivers and the magnitude, but infrequency, of the large floods, it is the in-channel flows that are most often targeted for abstraction. This is likely to vastly increase the length of time waterholes are disconnected (Bunn et al. 2006a) and may constrain or prevent many important processes associated with connection such as replenished water levels, improved water quality (Sheldon and Fellows this issue) and fish survival (Arthington et al. this issue).

In summary, waterholes in dryland rivers act as vital refugia in an otherwise arid environment. They maintain riverine diversity and ecosystem function during the extended no-flow periods between the highly variable but infrequent large flood events. In-channel flows, or flow pulses, are important for maintaining connection among waterholes and their physical persistence, facilitating dispersal and mediating water quality. We suggest that hydrological variability, through the connection and disconnection of waterholes, is a fundamental attribute of these dryland river systems; and, given the importance of spatial heterogeneity to assemblage structure (Arthington et al. 2005; Marshall et al. 2006; McGregor et al. 2006), a mosaic of refugia with different connection 'regimes' would be required for the full suite of species to be maintained in a conservation or restoration sense. Landuse patterns and water resource developments that change the connection frequency or permanency of the waterholes will have substantial impacts not only on the functioning of the waterholes themselves, but also on the diversity and resilience of the entire river system and its capacity to respond to the unpredictable flooding when it occurs. Maintaining the natural hydrological variability of dryland rivers is essential from a conservation perspective. 


\section{Acknowledgements}

The work for this paper was funded by the Cooperative Research Centre for Freshwater Ecology through the Dryland River Refugia Project. We thank all the members of the Dryland River Refugia Project Team for their input including colleagues from the Australian Rivers Institute at Griffith University, the Queensland Department of Environmental 445 Resource Management, the University of Canberra, the Murray-Darling Basin Freshwater Research Centre (Northern Basin Laboratory) and the New South Wales Department of Water. We are also indebted to landowners Bob Morrish (Springfield), Angus Emmott (Noonbah), Sandy Kidd (Mayfield), David Smith (Hammond Downs) and George Scott (Tanbar) for allowing access to waterholes on their properties and for their hospitality and 450 encouragement. We also thank three anonymous reviewers and the editor for very helpful comments on the manuscript. 


\section{References}

Andren, H. (1996). Population responses to habitat fragmentation: statistical power and the random sample hypothesis. Oikos 76, 235-242.

Amoros, C., and Bornette, G. (2002). Connectivity and biocomplexity in waterbodies of riverine floodplains. Freshwater Biology 47, 761-776.

Arthington, A. H., Balcombe, S. R., Wilson, G. A., Thoms, M. C., and Marshall, J. C. (2005). Spatial and temporal variation in fish assemblage structure in isolated waterholes during the 2001 dry season of an arid-zone floodplain river, Cooper Creek, Australia. Marine and Freshwater Research 56, 1-11.

Arthington, A. H., Olden, J. D., Balcombe, S. R., and Thoms, M. C. (this issue). Interacting and hierarchical factors explain fish assemblage turnover and quality of waterholes as refugia in Cooper Creek. Marine and Freshwater Research

Balcombe, S. R., and Arthington, A. H. (2009). Temporal changes in fish abundance in response to hydrological variability in a dryland floodplain river. Marine and Freshwater Research 60, 146-159.

Balcombe, S. R., Bunn, S. E., Arthington, A. H., Fawcett, J. H., McKenzie-Smith, F. J. et al. (2007). Fish larvae, growth and biomass relationships in an Australian arid zone river: links between floodplains and waterholes. Freshwater Biology 52, 2385-2398.

Balcombe, S. R., Bunn, S. E., McKenzie-Smith, F. J., and Davies, P. M. (2005). Variability of fish diets between dry and flood periods in an arid zone floodplain river. Journal of Fish Biology 67, 1552-1567.

Breen, C. (1991). Are intermittently flooded wetlands of arid environments important conservation sites? Madoqua 17, 61-65.

Bornette, G., Amoros, C., and Lamouroux, N. (1998). Aquatic plant diversity in riverine wetlands: the role of connectivity. Freshwater Biology 39, 27-283.

Boulton, A. J., and Lloyd, L. N. (1992). Flooding frequency and invertebrate emergence from dry floodplain sediments of the River Murray, Australia. Regulated Rivers: Research and Management 7, 137-151.

Bunn, S. E., and Arthington, A. H. (2002). Basic principles and consequences of altered hydrological regimes for aquatic biodiversity. Environmental Management 30, 492-507.

Bunn, S. E., and Davies, P. M. (1999). Aquatic food webs in turbid, arid zone rivers: Preliminary data from Cooper Creek, Queensland. In 'Free-Flowing River: The Ecology 
of the Paroo River' (Ed. R. T. Kingsford.) pp. 67-76 (New South Wales National Parks and Wildlife Service: Sydney.)

Bunn, S. E., Balcombe, S. R., Davies, P. M., Fellows, C. S., and McKenzie-Smith, F. J. (2006a). Aquatic productivity and food webs of desert river ecosytems. In 'Ecology of Desert Rivers. (Ed. R. T. Kingsford.) pp. 76-99. (Cambridge University Press: Cambridge.)

Bunn, S. E., Davies, P. M., and Winning, M. (2003). Sources of organic carbon supporting the food web of an arid zone floodplain river. Freshwater Biology 48, 619-635.

Bunn, S. E., Thoms, M. C., Hamilton, S. K., and Capon, S. J. (2006b). Flow variability in dryland rivers: Boom, bust and the bits in between. River Research and Applications 22, 179-186.

Burford, M., Cook, A., Fellows, C. S., Balcombe, S. R., and Bunn, S. E. (2008). Sources of carbon fuelling production in an arid floodplain river. Marine and Freshwater Research 59, $224-234$.

Carini G., and Hughes J. M. (2004). Population structure of Macrobrachium australiense (Decapoda: Palaemonidae) in Western Queensland, Australia: the role of contemporary and historical processes. Heredity 93, 350-363.

Carini G., and Hughes J. M. (2006). Population genetic structure and phylogeography of an endangered freshwater snail, Notopala sublineata (Gastropoda: Viviparidae) in Western Queensland, Australia. Biological Journal of the Linnean Society 88, 1-16.

Carini, G., Hughes, J. M., and Bunn, S. E. (2006). The role of waterholes as 'refugia' in sustaining genetic diversity and variation of two freshwater species in dryland river systems (Western Queensland, Australia). Freshwater Biology 51, 1434-1446.

Capon, S. J. (2003). Plant community responses to wetting and drying in a large arid floodplain. River Research and Applications 19, 509-520.

Cook B. D., Bunn S. E., and Hughes J. M. (2002). Genetic structure and dispersal of Macrobrachium australiense (Decapoda: Palaemonidae) in Western Queensland, Australia. Freshwater Biology 47, 2098-2112.

Cooper, S., Barmuta, L., Sarnelle, O., Kratz, K., and Diehl, S. (1997). Quantifying spatial heterogeneity in streams. Journal of the North American Benthological Society 16, 174188. 
Davis, L., Thoms, M. C., Fellows, C. S., and Bunn, S. E. (2002). Physical and ecological associations in dryland refugia: waterholes of the Cooper Creek, Australia. In 'The Structure, Function and Management Implications of Fluvial Sedimentary Systems' (Eds F. J. Dyer, M. C. Thoms and J. M. Olley), pp77-84 (Publ. no. 276. IAHS Press: Wallingford.)

Davies B. R., Thoms M. C., Walker K. F., O’Keefe J. H., and Gore J.A. (1994). Dryland rivers: their ecology, conservation and management. In 'The Rivers Handbook, Vol. 2' (Eds P. Calow and G.E. Petts), pp. 484-511. (Blackwell Scientific: Oxford.)

Dudgeon, D. (1996). The influence of refugia on predation impacts in a Hong Kong stream. Archiv feur Hydrobiologie 138, 145-159.

Dynesius, M., and Nilsson, C. (1994). Fragmentation and flow regulation of river systems in the northern third of the world. Science 266, 753-762.

Fellows, C. S., Bunn, S. E., Sheldon, F., and Beard, N. J. (2009). Benthic metabolism in two turbid dryland rivers. Freshwater Biology 54, 236-253.

Gustafsson, E. J., and Gardner, R. H. (1996). The effect of landscape heterogeneity on the probability of patch colonisation. Ecology 77, 94-107.

Hamilton, S. K., Bunn, S. E. Thoms, M. C., and Marshall, J. C. (2005). Persistence of aquatic refugia between flow pulses in a dryland river system (Cooper Creek, Australia). Limnology and Oceanography 50, 743-754.

Heiler, G., Hein, T., and Schiemer, F. (1995). Hydrological connectivity and flood pulses as the central aspects for the integrity of a river-floodplain system. Regulated Rivers: Research and Management 11, 351-361.

Holmquist, J. G. (1998). Permeability of patch boundaries to benthic invertebrates: influences of boundary contrast, light level, and faunal density and mobility. Oikos 81, 558-566.

Huey, J. A., Baker, A. M., and Hughes, J. M. (in review). Evidence for multiple historical colonisations of an endoreic drainage basin by an Australian freshwater fish. Molecular Ecology

Huey, J. A., Hughes, J. M., and Baker, A. M. (2006). Patterns of gene flow in two species of eel-tailed catfish, Neosilurus hyrtlii and Porochilus argenteus (Siluriformes: Plotosidae), in western Queensland;s dryland rivers. Biological Journal of the Linnean Society 87, 457-467.

Hughes, J. M., and Hillyer, M. J. (2006). Mitochondrial DNA and allozymes reveal high dispersal abilities and historical movement across drainage boundaries in two species of 
freshwater fishes from inland rivers in Queensland, Australia. Journal of Fish Biology 68 (Supplement B), 270-291.

Hughes, J. M., Baker, A. M., Bartlett, C., Bunn, S. E., Goudkamp, K., et al. (2004). Past and present patterns of connectivity among populations of four cryptic species of freshwater mussels Velesunio spp. (Hyriidae) in central Australia. Molecular Ecology 13, 31973212.

Hughes, J. M., Bunn, S. E., Kingston, D. M., and Hurwood, D. A. (1995). Genetic differentiation and dispersal among populations of Paratya australiensis (Atyidae) in rainforest streams in south-east Queensland, Australia. Journal of the North American Benthological. Society 14, 158-173.

Jackson J. K., and Resh V. J. (1992). Variation in genetic structure among populations of the caddisfly Helicopsyche borealis from three streams in northern California, U.S.A. Freshwater Biology, 27, 29-42.

Jenkins, K. M., and Boulton, A. J. (2003). Connectivity in a dryland river: short-term aquatic microinvertebrate recruitment following floodplain inundation. Ecology 84, 2708-2723.

Johnson, B. L., Knights, B. C., Barko, J. W., Gaugush, R. F., Soballe, D. M., et al. (1998). Estimating flow rates to optimise winter habitat for centrarchid fish in Mississippi River (USA) backwaters, Regulated Rivers: Research and Management 14, 499-510.

Junk, W. J., Bayley, P. B., and Sparks, R. E. (1989). The flood pulse concept in riverfloodplain systems. Canadian Special Publications of Fisheries and Aquatic Sciences 106, $110-127$

Kennard, M. J. (1995). Factors influencing freshwater fish assemblages in floodplain lagoons of the Normanby River, Cape York Peninsula: a large subtropical river. Masters thesis, Griffith University, Australia.

Kingsford, R. T. (2000a). Protecting rivers in arid regions or pumping them dry? Hydrobiologia 427, 1-11.

Kingsford, R. T. (2000b). Ecological impacts of dams, water diversions and river management on floodplain wetlands in Australia. Austral Ecology 25, 109-127.

Kingsford, R. T. (2006). Changing desert rivers. In 'Ecology of Desert Rivers'. (Ed. R.T. Kingsford.) pp. 336-345. (Cambridge University Press: Cambridge.)

Kingsford, R. T. (this issue). Australian waterbirds - time and space travellers in dynamic desert landscapes. Marine and Freshwater Research 
Kingsford, R. T., and Thompson, J. R. (2006). Desert or dryland rivers of the world: an introduction. In 'Ecology of Desert Rivers'. (Ed. R.T. Kingsford.) pp. 3-10. (Cambridge University Press: Cambridge)

Kingsford, R. T., Boulton, A. J., and Puckridge, J.T. (1998). Challenges in managing dryland rivers crossing political boundaries: Lessons from Cooper Creek and the Paroo River, central Australia. Aquatic Conservation: Marine and Freshwater Ecosystems 8, 361-378.

Kingsford, R. T., Curtin, A. L., and Porter, J. L. (1999). Water flows on Cooper Creek determine "boom” and "bust” periods for waterbirds. Biological Conservation 88, 231248.

Knighton, A. D., and Nanson, G. C. (1994). Waterholes and their significance in the anastomosing channel system of the Cooper Creek, Australia. Geomorphology 9, 311324.

Lancaster, J., and Belyea, L. R. (1997). Nested hierarchies and scale-dependence of mechanisms of flow refugium use. Journal of the North American Benthological Society 16, $221-238$.

Larned, S. T., Datry, T., Arscott, D. B., and Tockner, K. (2010). Emerging concepts in temporary-river ecology. Freshwater Biology 55, 717-738.

Leigh, C., Sheldon, F., Kingsford, R. T., and Olley, J. (this issue). Sequential flooding: the driver of 'booms' in dryland rivers. Marine and Freshwater Research.

Lemly, D., Kingsford, R. T., and Thompson, J. R. (2000). Irrigated agriculture and wildlife conservation: conflict on a global scale. Environmental Management 25, 485-512.

Loreau, M. (2000). Biodiversity and ecosystem functioning: recent theoretical advances. Oikos 91, 3-17.

Loutit, R. (1991). Western flowing ephemeral rivers and their importance to wetlands in Namibia. Madoqua 17, 135-140.

Lundberg, J., and Moberg, F. (2003). Mobile link organisms and ecosystem functioning: Implications for ecosystem resilience and management. Ecosystems 6, 87-98

Lutton, S., Sheldon, F., and Bunn, S. E. (2010). Morphological characteristics of on-farm 610 water storages and their similarity to natural water bodies in the Border Rivers Catchment, Australia. Aquatic Conservation: Marine and Freshwater Ecosystems 20, 4757. 
Lynch, R. J., Bunn, S. E., and Catterall, C. P. (2002). Adult aquatic insects: Potential contributors to riparian food webs in Australia's wet-dry tropics. Austral Ecology 27, 515-526.

Magalhaes, M. F., Beja, P., Schlosser, I. J., and Collares-Pereira, M. J. (2002). Effects of multi-year droughts on fish assemblages of seasonally drying Mediterranean streams. Freshwater Biology 52, 1494-1510.

Marshall, J. C., Sheldon, F., Thoms, M. C., and Choy, S. (2006). The macroinvertebrate fauna of an Australian dryland river: spatial and temporal patterns and environmental relationships. Marine and Freshwater Research 57, 61-74.

McGregor, G. B., Marshall, J. C., and Thoms, M. C. (2006). Spatial and temporal variation in algal-assemblage structure in isolated dryland river waterholes, Cooper Creek and Warrego River, Australia. Marine and Freshwater Research 57, 453-466.

McMahon, T. A., and Finlayson, B. L. (2003). Droughts and anti-droughts: the low flow hydrology of Australian rivers. Freshwater Biology 48, 1147-1160.

Morton, S. J., Short, J., and Baker, R. D. (1995). Refugia for biological diversity in arid and semi-arid Australia. Biodiversity Series, Paper No. 4. Report to the Biodiversity Unit of the Department of Environment, Sport and Territories, Canberra.

Medeiros, S. E .F., and Arthington, A. H. (2008). The importance of zooplankton in the diets of three native fish species in floodplain waterholes of a dryland river, the Macintyre River, Australia. Hydrobiologia 614, 19-31.

Nekola, J. C. (1999). Paleorefugia and neorefugia: the influence of colonisation history on community pattern and process. Ecology 80, 2459-2473.

Poff, N. L. (1997). Landscape filters and species traits: towards mechanistic understanding and prediction in stream ecology. Journal of the North American Benthological Society 16, 391-409.

Puckridge, J. T. (1999). The role of hydrology in the ecology of Cooper Creek, South Australia. Ph D Thesis, University of Adelaide, Australia.

Puckridge, J. T., Reid, J. R., Sheldon, F., and Baker, S. (1999). Biological survey of the Lower Diamantina floodplain, November 1993, Final Report. South Australian Department of Environment and Planning, the Australian Heritage Commission, and the Conservation Council of South Australia, Adelaide.

Puckridge, J.T., Sheldon, F., Walker, K. F., and Boulton, A. J. (1998). Flow variability and the ecology of large rivers. Marine and Freshwater Research 49, 55-72. 
Puckridge, J. T., Walker, K. F., and Costelloe, J. F. (2000). Hydrological persistence and the ecology of dryland rivers. Regulated Rivers: Research and Management 16, 385-402.

Rank, N. (1992) A hierarchical analysis of genetic variation in the montane leaf beetle Chrysomela aeneicollis (Coleoptera: Chrysomelidae). Evolution 46, 1097-1111.

Rempel, L. L., Richardson, J. S., and Healey, M. C. (1999). Flow refugia for benthic macroinvertebrates during flooding of a large river. Journal of the North American Benthological Society 18, 34-48.

Roshier, D., Doerr, V., and Doerr, E. (2008). Animal movement in dynamic landscapes: interaction between behavioural strategies and resource distributions. Oecologia 156, 465-477.

Sedell, J. R., Reeves, G. H., Hauer, F. R., Stanford, J. A., and Hawkins, C. P. (1990). Role of refugia in recovery from disturbances: modern fragmented and disconnected river systems. Environmental Management 14, 711-724.

Sheldon, F., and Fellows, C. S. (this issue) Temporal and spatial variability of water quality and water chemistry in two Australian dryland rivers. Marine and Freshwater Research

Sheldon, F., and Puckridge, J. T. (1998). Macroinvertebrate assemblages of Goyder Lagoon, Diamantina River, South Australia. Transactions of the Royal Society of South Australia 122, 17-31.

Sheldon, F., and Thoms, M. C. (2006). Relationships between flow variability and invertebrate community composition: data from four Australian dryland rivers. River Research and Applications 22, 219-238

Sheldon, F., Boulton, A. J., and Puckridge, J. T. (2002). Conservation value of variable connection: Aquatic invertebrate assemblages of channel and floodplain habitats of a central Australian arid-zone river, Cooper Creek. Biological Conservation 103, 13-31.

Slatkin, M. (1985) Gene flow in natural populations. Annual Review of Ecology and Systematics, 16, 393-430.

Sweeney, B. W., Funk, D. H., and Vannote, R. L. (1986). Population genetic structure of two mayflies (Ephemerella subvaria, Eurylophella verisimilis) in the Delaware River drainage basin. Journal of the North American Benthological Society 5, 253-262.

Thoms, M. C., and Sheldon, F. (2000a). Lowland rivers: an Australian perspective. Regulated Rivers Research and Management 16, 375-383. 
Thoms, M. C., and Sheldon, F. (2000b). Water resource development and hydrological change in a large dryland river: The Barwon-Darling River, Australia. Journal of Hydrology 228, 10-21.

Tockner, K., and Stanford, J. A. (2002). Riverine flood plains: present state and future trends. Environmental Conservation 29, 308-330.

Tockner, K., Malard, F., and Ward, J. V. (2000). An extension of the flood pulse concept. Hydrological Processes 14, 2861-2883.

Tockner, K., Schiemer, F., Baumgartner, C., Kum, G., Weigand, E., et al. (1999). The Danube restoration project: Species diversity patterns across connectivity gradients in the floodplain system. Regulated Rivers: Research and Management 15: 245-258.

Tooth, S. (2000). Process, form and change in dryland rivers: a review of recent research. Earth-Science Reviews 51, 67-107.

Torgersen, C. E., Price, D. M., Li, H. W., and McIntosh, B. A. (1999). Multiscale thermal 690 refugia and stream habitat associations of chinook salmon in northeastern Oregon. Ecological Applications 9, 301-319.

Vannote, R. L., Minshall, G. W., Cummins, K. W., Sedell, J. R., and Cushing, C. E. (1980). The river continuum concept. Canadian Journal of Fisheries and Aquatic Sciences 37, 130-137.

Walker, K. F., Sheldon, F., and Puckridge, J. T. (1995). An ecological perspective on large dryland rivers. Regulated Rivers: Research and Management 11, 85-104.

Waples, R. S. (1987). A multispecies approach to the analysis of gene flow in marine shore fishes. Evolution, 41, 385-400.

Ward, J. V., and Stanford, J. A. (1995). The serial discontinuity concept: extending the model to floodplain rivers. Regulated Rivers: Research and Management 10, 159-168.

Ward, J. V., Tockner, K., and Schiemer, F. (1999). Biodiversity of floodplain river ecosystems: ecotones and connectivity. Regulated Rivers: Research and Management 15, 125-139.

Winterbottom, J. H., Orton, S. E., Hildrew, A. G., and Lancaster, J. (1997). Field experiments on flow refugia in streams, Freshwater Biology 37, 569-580.

Wood, P. J., and Petts, G. E. (1999). The influence of drought on chalk stream macroinvertebrates, Hydrological Processes 13, 387-399. 
Figure 1. (a) Areas of dryland rivers in Australia covering (i) the western portion of the Murray-Darling Basin and the Lake Eyre Basin; shaded in light grey, and (ii) the south westerly portion of the north-east coastal rivers and, in Western Australia, the rivers of the Gascoyne Basin and Murchison Basin; shaded in dark grey. (b) Murken Waterhole, a typical refugial waterhole on Cooper Creek, Lake Eyre Basin, photo courtesy of Steve Hamilton.

Figure 2: Different dispersal strategies used by organisms in fragmented river landscapes. Waterholes denoted in grey contain water, whereas those in white are dry. Arrows depict movement of organisms within and between waterholes.

Figure 3: Hypothesised shifts in assemblage composition through phases of waterhole connection and disconnection displayed using hypothetical multi-dimensional scaling plots. During waterhole connection (a) there is little dissimilarity between assemblages of different waterholes. After disconnection (b) assemblage composition and structure of distinct waterholes diverges in response to both different abiotic (water quality, habitat) and biotic (competition and predation) factors. After prolonged disconnection (c) environmental attributes of disconnected waterholes become increasingly harsh and the assemblage is dominated by tolerant generalists, reducing assemblage dissimilarity between distant waterholes.

Figure 4. Conceptual models of processes occurring in a dryland river waterhole under different flow conditions. (I) Connection caused by episodic in-channel surface flow events: no littoral primary production due to brief inundation and flowing water; high turbidity limits profundal production; surface flow (curved arrows) provides inputs and mixing of nutrients and conditions for the dispersal of fish and invertebrates. (II) Disconnection of waterholes, connection ceases and waterholes are isolated. (a) Initially rapid drawdown to waterhole sill height (black arrows); low benthic and pelagic algal production; organisms are 'trapped' in 740 the isolated waterholes, abundances are initially high, but overcrowding and low food availability means condition declines. (b) Eventually high evapotranspiration (grey arrows) reduces water levels; algal bathtub ring establishes (thick grey band on waterhole edge); pelagic phytoplankton appears reflecting flow generated nutrient availability; high invertebrate and zooplankton biomass; reduced fish biomass means fish condition improves. (c) Months after flow ceases water levels become more stable; evapotranspiration continues; groundwater inputs are variable and dependent on local conditions (white arrows); increasingly stable water levels fuel high littoral algal production (thick grey band); high benthic invertebrate production; high zooplankton production; trapped fish grow and reproduce. 


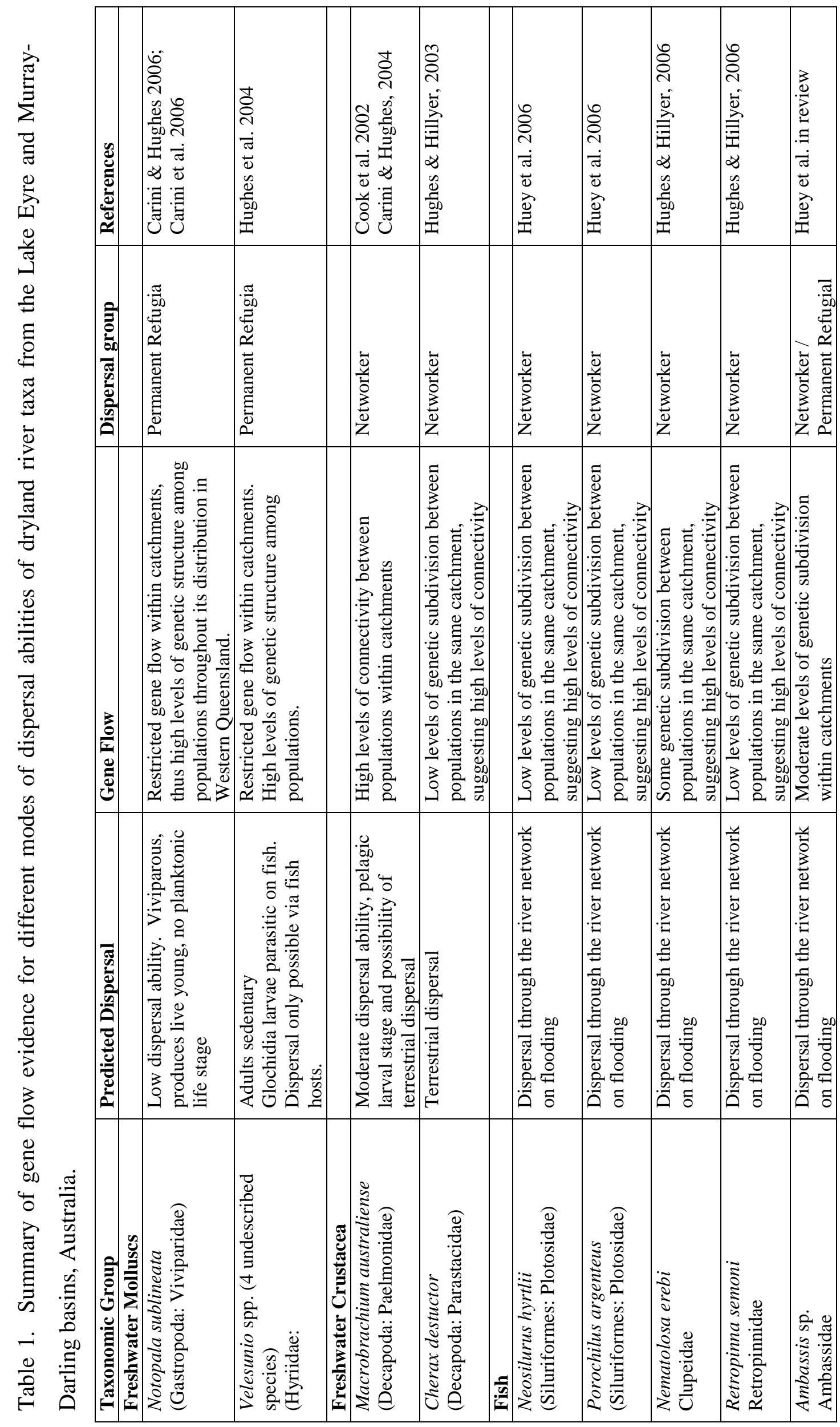

공
공 
Figure 1
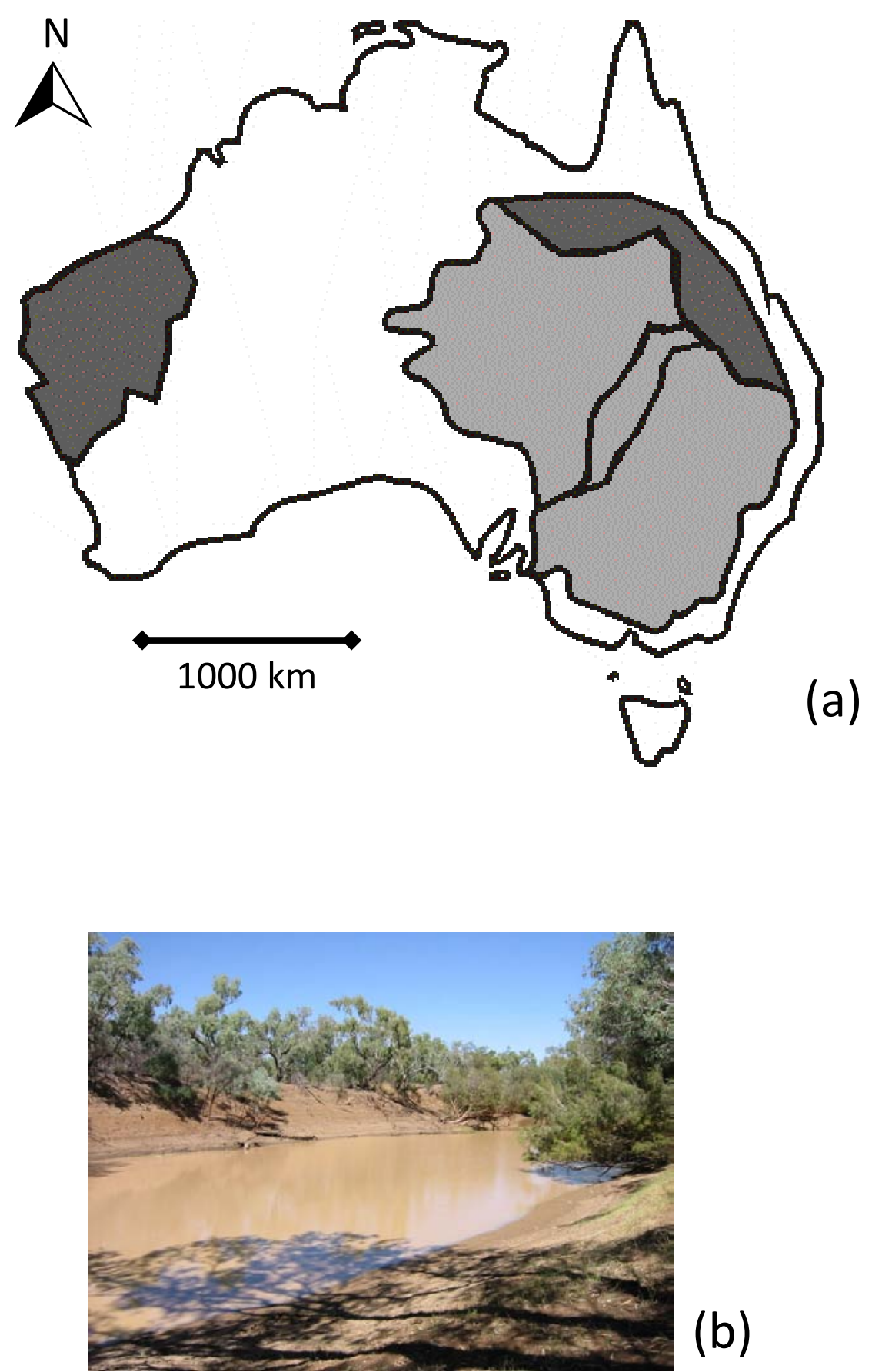

(b) 
Figure 2

"Movers" - Mobile-link organisms

Disperse relatively easily between

suitable habitats, don't require flow as

a connector.

e.g. Hemiptera, Coleoptera
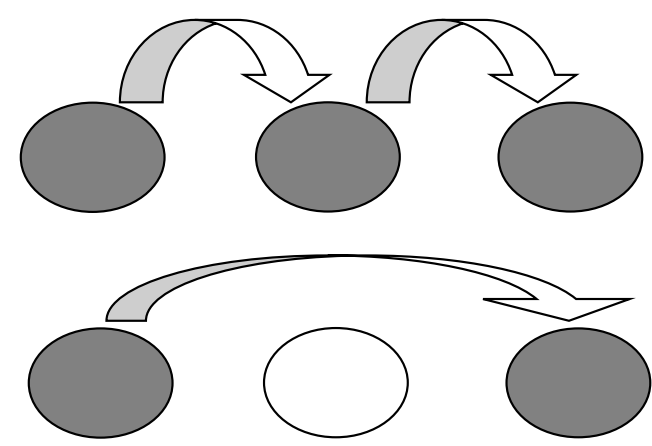

"Networker" organisms

Disperse relatively easily between

waterholes using flow as a connector in

the channel network.

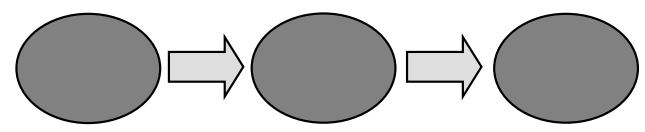

e.g. Crustaceans, some fish

"Permanent Refugial" organisms

Limited dispersal between waterholes

even under flow conditions.

e.g. Snails, mussels, some fish
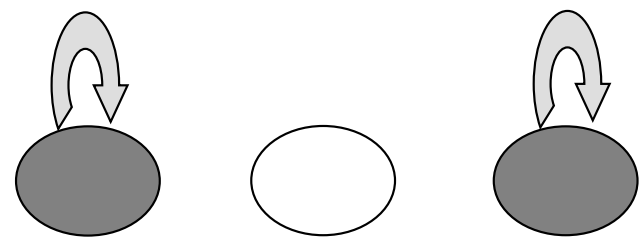
Figure 3

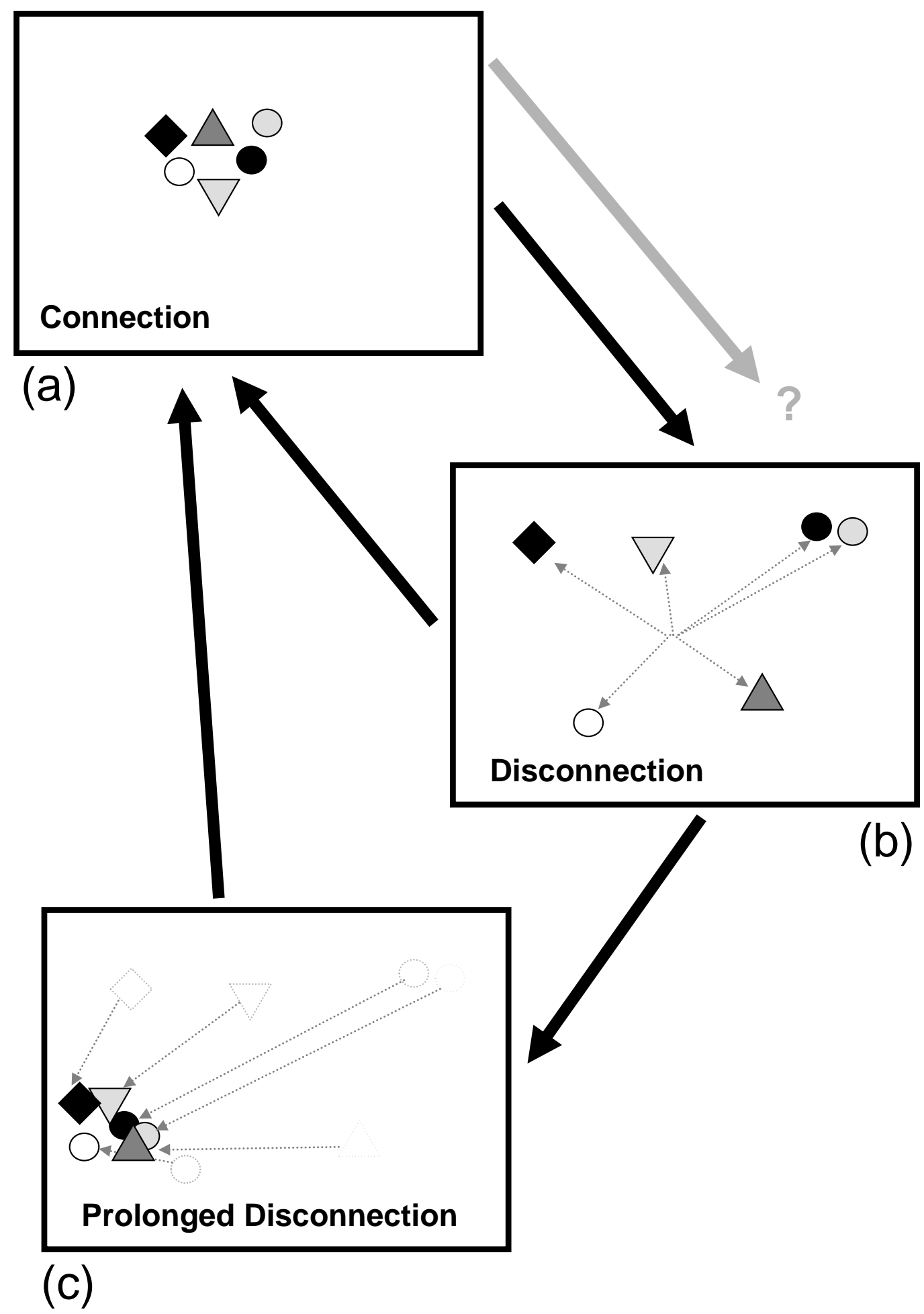


Figure 4

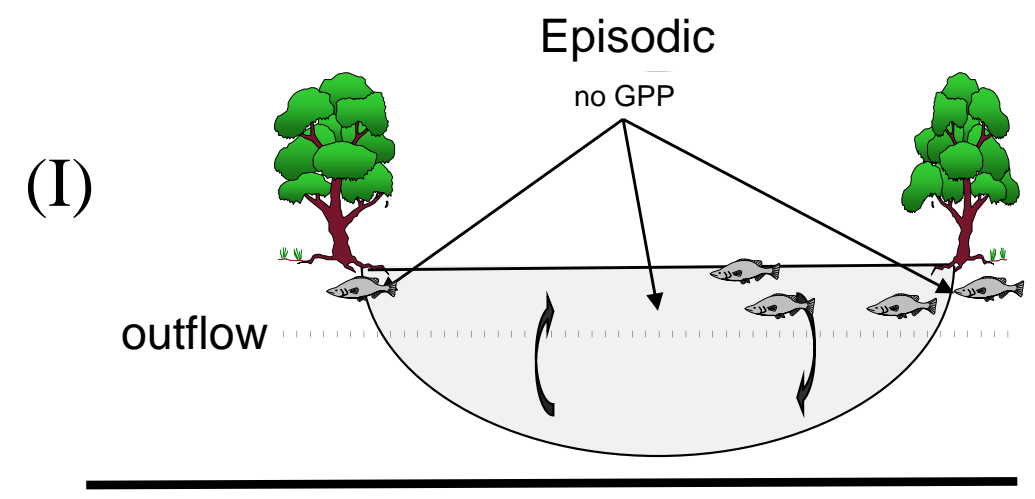

(a)

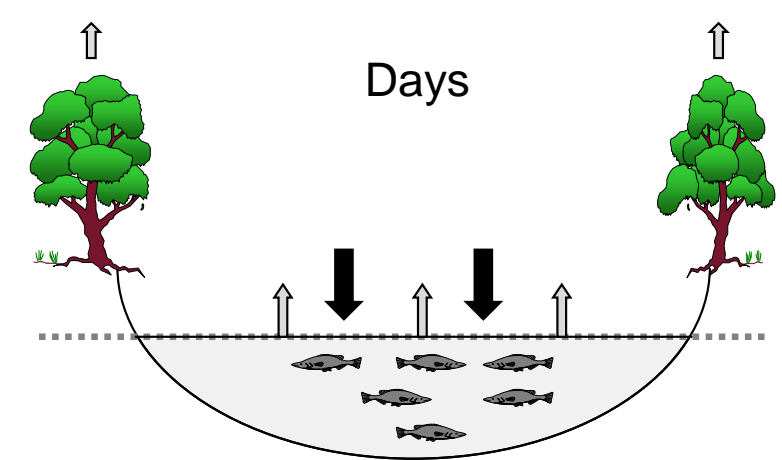

(II)

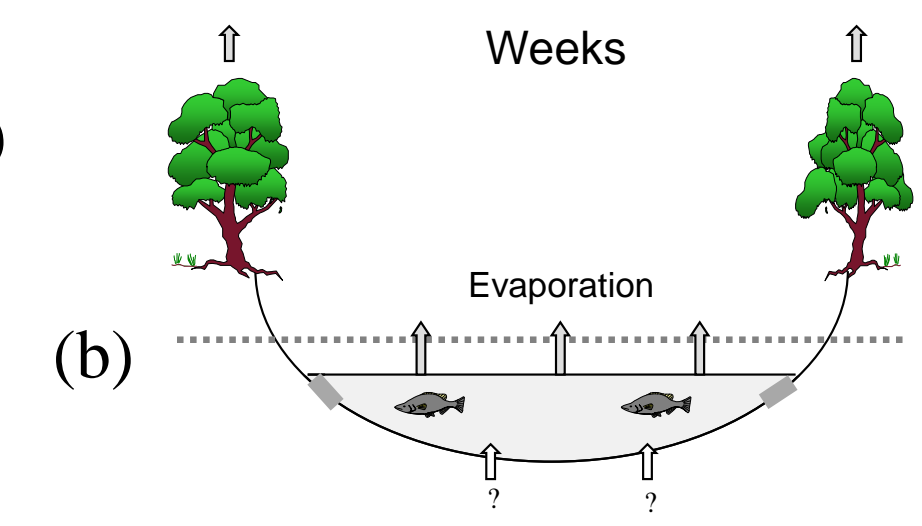

(b)

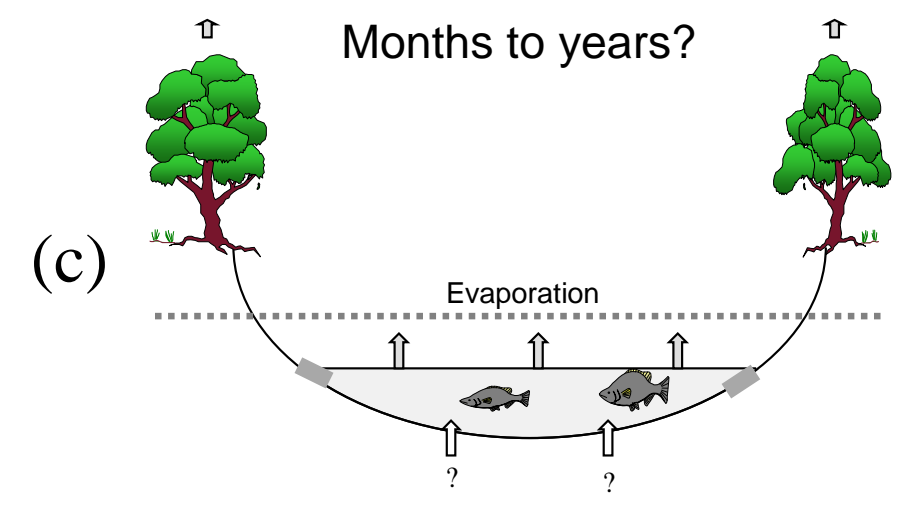

